\title{
Influence of different sources of injected selenium on certain enzymes, glutathione and adenosylmethionine concentration in buffalo (Bubalus bubalis) calves
}

\author{
BY T. PRASAD AND S. P. ARORA \\ National Dairy Research Institute, Karnal-132 001, Haryana, India
}

(Received 31 July 1990 - Accepted 10 December 1990)

\begin{abstract}
Sodium selenite and selenomethionine were investigated as possible causative factors for the induction of Degnala disease syndrome in twelve buffalo (Bubalus bubalis) calves divided into three groups of four. Group 1 was the control group and received no additional selenium. Sodium selenite and selenomethionine were given daily as intramuscular injections on a selenium-equivalent basis, with a weekly increment in the dose of $0.05 \mathrm{mg} \mathrm{Se} / \mathrm{kg}$ live weight from 0.05 to $0.20 \mathrm{mg} \mathrm{Se} / \mathrm{kg}$ live weight per day, in groups 2 and 3 respectively. Only one animal from group 3 manifested the lesions of Degnala disease. The blood Se concentration and erythrocyte glutathione peroxidase (EC 1.11.1.9; GSH-Px) activity were both greater in groups 2 and 3 than in control group 1. The overall blood Se concentration was 0.22 (SE 0.01), 0.38 (SE 0.12) and 0.77 (SE 0.20) $\mu \mathrm{g} \mathrm{Se} / \mathrm{ml}$ in groups 1 to 3 respectively with corresponding GSH-Px activities of 63.84 (SE 7.38), 88.37 (SE 12.38) and 165.32 (SE 40.62) enzyme units/mg protein. Erythrocyte glutathione reductase $(\mathrm{NAD}(\mathrm{P}) \mathrm{H})(E C$ 1.6.4.2) activity was not affected by treatment but reduced glutathione content was lower in groups 2 and 3 . Liver adenosylmethionine, estimated at autopsy, was lowest (22.87 (SE 6.17) $\mu \mathrm{mol} / \mathrm{g})$ in group 3, and greatest (102.63 (SE 9.39) $\mu \mathrm{mol} / \mathrm{g})$ in group $1(P<0.01)$. Organic Se sources seemed to accumulate in tissues more than inorganic sources, and might be the causative toxic factors of Degnala disease.
\end{abstract}

Glutathione peroxidase: Adenosylmethionine: Selenium

Chronic selenosis is known to occur in some areas of certain geographical zones. A high selenium content in certain straws and fodders, as high as $6.7 \mathrm{mg} / \mathrm{kg}$, has been reported to cause Degnala disease in buffaloes and cattle in India (Arora et al. 1975; Prasad \& Arora, 1984). Rice straw accumulates Se to the extent of 8.06-11.56 times the Se content of soil (Prasad \& Arora, 1980). Certain inorganic forms of Se, such as sodium selenite and sodium selenate in the diet, affect liver cells causing a serious and often fatal disorder (Khirwar \& Arora, 1975), but Se which is available in the organic form from certain plants seems to affect liver more severely (Rosenfeld \& Beath, 1964; Mathias et al. 1967). The exact way in which the inorganic and organic forms of Se at toxic levels interfere with tissue structure and function is unclear. It is likely that certain detoxifying mechanisms may become operative in enhancing the process of Se excretion in the form of its methyl derivatives, such as the trimethyl selenonium ion in urine or dimethyl selenide in exhaled air (Ganther \& Hsieh, 1974).

In the present study an attempt has been made to obtain information on the detoxification process occurring with systemic loads of organic and inorganic forms of Se by estimating the activity of enzymes glutathione peroxidase (EC 1.11.1.9; GSH-Px) and glutathione reductase (NAD $(\mathrm{P}) \mathrm{H})(E C$ 1.6.4.2; GSSG-R) and concentrations of related metabolites adenosylmethionine (SAM) and reduced glutathione (GSH). 
Table 1. Feeding regimen used in the experiment (Sen et al. 1978)

\begin{tabular}{|c|c|c|c|c|c|}
\hline \multirow[b]{2}{*}{ Group } & \multirow[b]{2}{*}{ Animal no. } & \multirow{2}{*}{\multicolumn{2}{|c|}{$\begin{array}{l}\text { Body-wt } \\
(\mathrm{kg})\end{array}$}} & \multicolumn{2}{|c|}{ Feed offered } \\
\hline & & & & $\begin{array}{l}\text { Concentrate } \\
(\mathrm{kg} / \mathrm{d})\end{array}$ & $\begin{array}{l}\text { Green maize } \\
\qquad(\mathrm{kg} / \mathrm{d})\end{array}$ \\
\hline \multirow[t]{5}{*}{1} & 2262 & & $94 \cdot 5$ & $1 \cdot 2$ & $5 \cdot 0$ \\
\hline & 2251 & & $119 \cdot 0$ & 1.4 & 5.0 \\
\hline & 2237 & & 121.0 & 1.4 & 5.0 \\
\hline & 2268 & & $79 \cdot 0$ & $1 \cdot 2$ & 4.0 \\
\hline & & Mean & $103 \cdot 38$ & & \\
\hline \multirow[t]{5}{*}{2} & 2286 & & $93 \cdot 5$ & $1 \cdot 2$ & $5 \cdot 0$ \\
\hline & E-2 & & $113 \cdot 5$ & 1.4 & 5.0 \\
\hline & 2202 & & $92 \cdot 0$ & 12 & 5.0 \\
\hline & 2232 & & $82 \cdot 0$ & $1 \cdot 2$ & $4 \cdot 0$ \\
\hline & & Mean & 95.25 & & \\
\hline \multirow[t]{5}{*}{3} & 2271 & & $118 \cdot 5$ & 1.4 & 5.0 \\
\hline & 2291 & & 107.0 & 1.4 & 50 \\
\hline & 2218 & & $130 \cdot 0$ & 1.5 & 5.0 \\
\hline & 2289 & & 88.0 & $1 \cdot 2$ & 4.0 \\
\hline & & Mean & $110 \cdot 88$ & & \\
\hline
\end{tabular}

\section{MATERIALS AND METHODS}

\section{Animals and management}

Twelve male Murrah buffalo (Bubalus bubalis) calves, with body-weights ranging from 79 to $130 \mathrm{~kg}$, were divided randomly into three equal groups (Table 1). The concentrate fed to the calves comprised $(\mathrm{g} / \mathrm{kg})$ : ground nut cake 430 , crushed maize 270 , wheat bran 270 and mineral mixture with sodium chloride 30 . The resultant mixture was found to contain $0.24 \mu \mathrm{g} \mathrm{Se} / \mathrm{kg}$ on a dry matter (DM) basis. The fodder source was green maize which contained $0.14 \mu \mathrm{g} \mathrm{Se} / \mathrm{kg}$ DM. The feeding regimen (Table 1) was computed according to Sen et al. (1978). After 1 month on this regimen, blood samples were taken and erythrocyte GSH-Px activity was determined. This value was taken as the level of the enzyme activity at week 0 .

\section{Se administration and blood collection}

The animals of control group 1 received no extra Se but those of group 2 were injected intramuscularly with sodium selenite, and those of group 3 with selenomethionine, each day on an Se-equivalent basis. The weekly increase in dose meant that at weeks 1, 2, 3 and 4 , the doses were $0 \cdot 05,0 \cdot 10,0 \cdot 15$ and $0.20 \mathrm{mg} \mathrm{Se} / \mathrm{kg}$ body-weight per $\mathrm{d}$ respectively. Blood samples were collected in heparinized tubes in ice every week before the injection of the next-higher dose, and brought to the laboratory for analysis.

\section{Measurement of enzyme activities in erythrocytes}

Whole blood $(0.5 \mathrm{ml})$ was pipetted into a centrifuge tube and the volume made up to $3 \mathrm{ml}$ with cold $0.4 \mathrm{M}$-phosphate buffer, $\mathrm{pH} 7.0$. The contents were mixed and centrifuged at $9000 \mathrm{~g}$ for $14 \mathrm{~min}$ at $4^{\circ}$. The supernatant fraction was syphoned off. The erythrocyte layer remaining at the bottom of the centrifuge tube was resuspended in buffer to a volume $3.0 \mathrm{ml}$, mixed and recentrifuged. After the second wash, the erythrocyte layer was haemolysed by addition of cold distilled water to a volume of $3.0 \mathrm{ml}$, and then mixed again. The GSH-Px and GSSG-R activities in the haemolysate were estimated by following the procedures of Hafeman et al. (1974) and King (1965) respectively. GSH concentration was 
Table 2. Whole-blood selenium concentration $(\mu \mathrm{g} / \mathrm{ml})$ of buffalo (Bubalus bubalis) injected daily with weekly incremental doses of sodium selenite (group 2) or selenomethionine (group 3)

\begin{tabular}{|c|c|c|c|c|c|c|c|}
\hline Group* & Animal no. & $\mathrm{W}_{0}$ & $w_{1}$ & $W_{2}$ & $\mathrm{w}_{3}$ & $W_{4}$ & Slope \\
\hline 1 (Control) & $\begin{array}{c}1 \\
2 \\
3 \\
4 \\
\text { Mean }\end{array}$ & $\begin{array}{l}0 \cdot 24 \\
0 \cdot 18 \\
0 \cdot 24 \\
0 \cdot 10 \\
0 \cdot 19\end{array}$ & $\begin{array}{l}0.26 \\
0.12 \\
0.22 \\
0.26 \\
0.21\end{array}$ & $\begin{array}{l}0.26 \\
0.16 \\
0.32 \\
0.24 \\
0.24\end{array}$ & $\begin{array}{l}0.21 \\
0.29 \\
0.22 \\
0.27 \\
0.25\end{array}$ & $\begin{array}{l}0.25 \\
0.20 \\
0.20 \\
0.20 \\
0.21\end{array}$ & $\begin{array}{r}-0.003 \\
-0.021 \\
-0.008 \\
0.021 \\
0.008^{\mathrm{a}}\end{array}$ \\
\hline 2 & $\begin{array}{c}1 \\
2 \\
3 \\
4 \\
\text { Mean }\end{array}$ & $\begin{array}{l}0 \cdot 18 \\
0 \cdot 04 \\
0.12 \\
0 \cdot 12 \\
0.11\end{array}$ & $\begin{array}{l}0 \cdot 24 \\
0 \cdot 14 \\
0 \cdot 12 \\
0 \cdot 19 \\
0 \cdot 17\end{array}$ & $\begin{array}{l}0.38 \\
0.26 \\
0.26 \\
0.44 \\
0.33\end{array}$ & $\begin{array}{l}0.60 \\
0.42 \\
0.50 \\
0.68 \\
0.55\end{array}$ & $\begin{array}{l}0.84 \\
1.00 \\
0.58 \\
0.64 \\
0.75\end{array}$ & $\begin{array}{l}0.168 \\
0.220 \\
0.130 \\
0.153 \\
0.166^{\mathrm{b}}\end{array}$ \\
\hline 3 & $\begin{array}{c}1 \\
2 \\
3 \\
4 \\
\text { Mean }\end{array}$ & $\begin{array}{l}0 \cdot 16 \\
0 \cdot 20 \\
0 \cdot 22 \\
0 \cdot 30 \\
0 \cdot 22\end{array}$ & $\begin{array}{l}0.34 \\
0.38 \\
0.27 \\
1.04 \\
0.51\end{array}$ & $\begin{array}{l}0.70 \\
0.40 \\
1.00 \\
0.82 \\
0.73\end{array}$ & $\begin{array}{l}1 \cdot 40 \\
1 \cdot 40 \\
1 \cdot 18 \\
1.70 \\
1.42\end{array}$ & $\begin{array}{l}0.82 \\
0.75 \\
0.80 \\
1.60 \\
0.99\end{array}$ & $\begin{array}{l}0.238 \\
0.212 \\
0.207 \\
0.326 \\
0.245^{\circ}\end{array}$ \\
\hline & & & & & & & SEM (df 9) \\
\hline
\end{tabular}

a, b. . Mean values with different superscript letters were significantly different $(P<0 \cdot 05)$.

$\mathrm{W}_{0}-\mathrm{W}_{4}$, weeks $0-4$ of the experiment.

* For details of treatments, see p. 262 and Table 1.

measured by the procedure of Prins \& Loos (1969) and protein concentration was determined by the procedure of Lowry et al. (1951). For Se concentration, $1.0 \mathrm{ml}$ whole blood was pipetted into a digestion tube and the determination was carried out using the fluorimetric procedure of Olson et al. (1975). Separate samples of whole blood were also taken in Wintrobe haemotocrit tubes for determination of packed cell volume.

\section{Liver SAM estimation}

The animals were killed on day 30 and liver samples were collected on ice and brought to the laboratory for analysis. The Dowex 50 sodium ion-exchange chromatographic procedure of Salvatore et al. (1971) was followed to estimate liver SAM concentration. The recovery of SAM was $93 \%$, indicating satisfactory separation of SAM from adenosylhomocysteine $(\mathrm{SAH})$. The isolated fractions were stable at $4^{\circ}$ for $24 \mathrm{~h}$.

\section{Statistical analysis}

The observations taken at $30 \mathrm{~d}$ were subjected to an analysis of variance for a completely randomized design (Snedecor \& Cochran, 1968). The observations made at weekly intervals from the start of the experiment (week 0 ) until week 4 were analysed by linear regression, and the resulting slopes were used in an analysis of variance for a completely randomized design, according to the method of Rowell \& Walters (1976). Means were compared using the studentized range test.

\section{RESULTS}

Blood Se concentration

The blood concentration remained approximately the same in group 1 at each of the weekly intervals (Table 2). The rate of change of blood Se concentration with time was greater in group 3 animals given selenomethionine than for those in group 2 given the inorganic form of Se on a Se-equivalent basis $(P<0 \cdot 05)$. 
Table 3. Erythrocyte glutathione peroxidase (EC 1.11.1.9) activity (EU/mg protein) of buffalo (Bubalus bubalis) injected daily with weekly incremental doses of sodium selenite (group 2) or selenomethionine (group 3)

\begin{tabular}{|c|c|c|c|c|c|c|c|}
\hline Group* & Animal no. & $\mathrm{W}_{0}$ & $\mathrm{~W}_{1}$ & $\mathrm{~W}_{2}$ & $\mathrm{~W}_{3}$ & $\mathrm{~W}_{4}$ & Slope \\
\hline 1 (Control) & $\begin{array}{c}1 \\
2 \\
3 \\
4 \\
\text { Mean }\end{array}$ & $\begin{array}{r}55 \cdot 54 \\
116.63 \\
74.03 \\
106.04 \\
88.06\end{array}$ & $\begin{array}{r}27 \cdot 47 \\
22.85 \\
109 \cdot 49 \\
132.88 \\
73.17\end{array}$ & $\begin{array}{l}37 \cdot 38 \\
59 \cdot 22 \\
57 \cdot 71 \\
77 \cdot 35 \\
57 \cdot 91\end{array}$ & $\begin{array}{l}28 \cdot 97 \\
37 \cdot 36 \\
57 \cdot 72 \\
75 \cdot 03 \\
49 \cdot 77\end{array}$ & $\begin{array}{l}21 \cdot 38 \\
45 \cdot 55 \\
49 \cdot 06 \\
85 \cdot 14 \\
50 \cdot 28\end{array}$ & $\begin{array}{r}-6.68 \\
-12.77 \\
-10 \cdot 17 \\
-9.97 \\
-9.90^{\mathrm{a}}\end{array}$ \\
\hline 2 & $\begin{array}{c}1 \\
2 \\
3 \\
4 \\
\text { Mean }\end{array}$ & $\begin{array}{l}53 \cdot 37 \\
87 \cdot 97 \\
43 \cdot 20 \\
54 \cdot 04 \\
59 \cdot 64\end{array}$ & $\begin{array}{r}104 \cdot 26 \\
69 \cdot 88 \\
108 \cdot 16 \\
76 \cdot 79 \\
89 \cdot 77\end{array}$ & $\begin{array}{r}128 \cdot 90 \\
70 \cdot 62 \\
144 \cdot 08 \\
80 \cdot 93 \\
106 \cdot 13\end{array}$ & $\begin{array}{r}95 \cdot 84 \\
75 \cdot 24 \\
123 \cdot 23 \\
166 \cdot 57 \\
115 \cdot 22\end{array}$ & $\begin{array}{l}55 \cdot 54 \\
95 \cdot 56 \\
53 \cdot 36 \\
79 \cdot 95 \\
71 \cdot 10\end{array}$ & $\begin{array}{r}-0 \cdot 41 \\
2 \cdot 05 \\
3 \cdot 54 \\
14 \cdot 16 \\
4 \cdot 84^{b}\end{array}$ \\
\hline 3 & $\begin{array}{c}1 \\
2 \\
3 \\
4 \\
\text { Mean }\end{array}$ & $\begin{array}{l}57 \cdot 86 \\
42 \cdot 01 \\
54 \cdot 03 \\
74 \cdot 04 \\
56 \cdot 98\end{array}$ & $\begin{array}{l}123.09 \\
206.04 \\
178 \cdot 03 \\
243.05 \\
187.55\end{array}$ & $\begin{array}{r}78 \cdot 28 \\
55 \cdot 87 \\
80 \cdot 03 \\
175 \cdot 60 \\
97 \cdot 45\end{array}$ & $\begin{array}{l}129 \cdot 60 \\
208 \cdot 85 \\
231 \cdot 65 \\
213 \cdot 37 \\
195 \cdot 86\end{array}$ & $\begin{array}{l}223 \cdot 28 \\
269 \cdot 18 \\
303 \cdot 93 \\
348 \cdot 57 \\
288 \cdot 74\end{array}$ & $\begin{array}{l}33 \cdot 74 \\
45 \cdot 72 \\
55 \cdot 34 \\
51 \cdot 94 \\
46 \cdot 68^{\circ}\end{array}$ \\
\hline & & & & & & & SEM (df 9) 3.39 \\
\hline
\end{tabular}

$n, b, e$ Mean values with different superscript letters were significantly different $(P<0-05)$.

$\mathrm{W}_{0}-\mathrm{W}_{4}$, weeks $0-4$ of the experiment; EU, enzyme unit.

* For details of treatments, see p. 262 and Table 1.

\section{Erythrocyte GSH-Px activity and liver SAM content}

The rates of change of erythrocyte GSH-Px activity differed significantly between treatments (Table 3). In general, it followed a trend similar to that of blood $\mathrm{Se}$ concentration and was highest in group 3 animals and lowest in group 1 animals. In group 2 , the enzyme activity tended to increase up to week 3 , thereafter there was a decrease in activity. In group 3 animals, the enzyme activity increased at each time-interval except at week 2. The higher activity of this enzyme in group 3 also suggested greater tissue Se accumulation from the organic form, which also led to the manifestation of clinical symptoms of Degnala disease in one animal (Plates 1 and 2).

The erythrocyte GSSG-R activity showed no difference with either form of Se (Table 4), indicating similar rates of Se excretion from the tissues. The latter effect was further substantiated by the observed trend of liver SAM concentration (Table 5), which was least in group 3 and greatest in group $1(P<0.01)$, indicating a higher Se methylation rate. Metabolic events seemed to occur at a faster rate with the organic form of Se than with the selenite form. GSH concentration did not show any trend with different treatments (Table 6).

\section{DISCUSSION}

The highest blood Se levels were observed in group 3 animals with the organic Se source, while there was no increase in group 1 animals, indicating that different Se sources have a different effect (Ehlig et al. 1967).

The increase in erythrocyte GSH-Px activity with increasing Se dose from different sources was proportional to the Se dose. Thus, GSH-Px is highly dependent on Se for its activity (Lee et al. 1969; Hafeman et al. 1974; Ganther et al. 1976; Kraus et al. 1983). GSHPx activity increased or decreased in certain groups at certain times which could be explained as a differential pattern of biological response to a given Se dose at one time. The 
Table 4. Erythrocyte glutathione reductase (EC 1.6.4.2) activity ( $\mathrm{mIU} / \mathrm{mg}$ protein) of buffalo (Bubalus bubalis) injected daily with weekly incremental doses of sodium selenite (group 2) or selenomethionine (group 3)

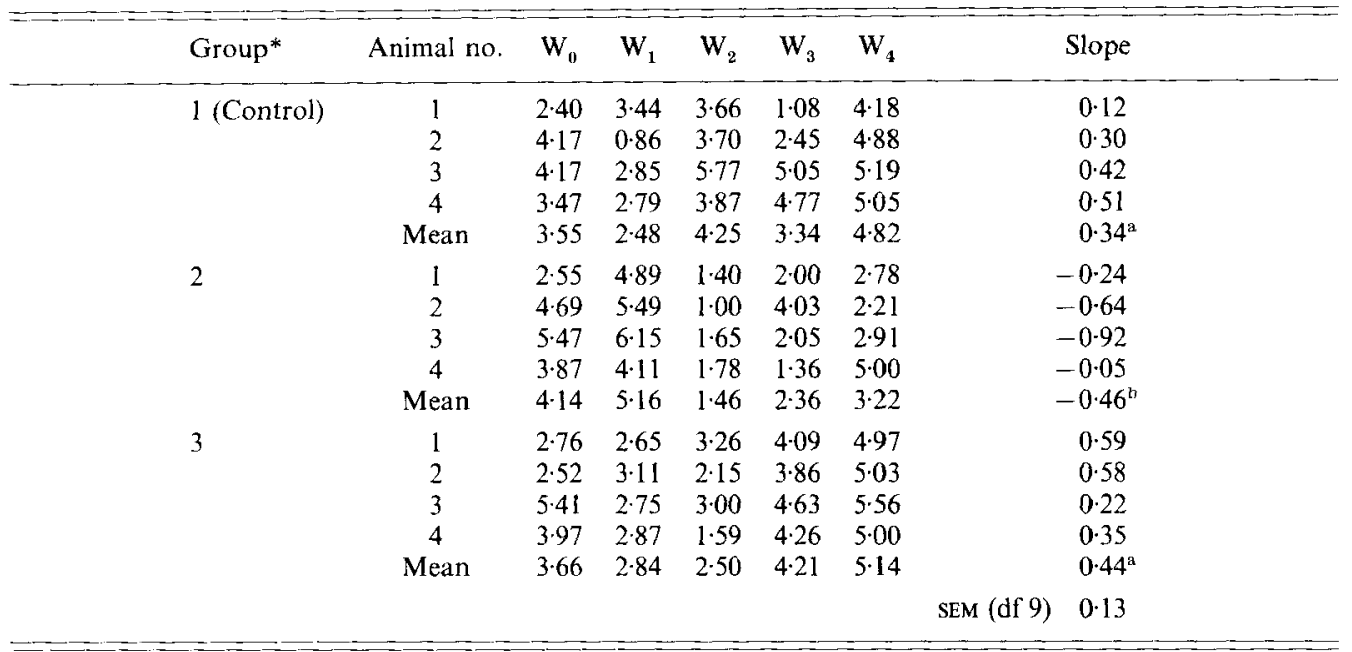

a. h. S Mean values with different superscript letters were significantly different $(P<0.05)$.

$\mathrm{W}_{0}-\mathrm{W}_{4}$, weeks $0-4$ of the experiment.

* For details of treatments, see p. 262 and Table 1.

Table 5. Liver adenosylmethionine $(S A M)$ contents ( $\mu$ mol/g fresh liver tissue) of buffalo (Bubalus bubalis) calves injected daily with weekly incremental doses of sodium selenite (group 2) or selenomethionine (group 3)

\begin{tabular}{|c|c|c|c|c|c|c|}
\hline \multirow[t]{2}{*}{ Group*... } & \multicolumn{2}{|c|}{1 (Control) } & \multicolumn{2}{|l|}{2} & \multicolumn{2}{|l|}{3} \\
\hline & Animal no. & SAM & Animal no. & SAM & Animal no. & SAM \\
\hline & 2262 & $90 \cdot 70$ & 2286 & $69 \cdot 40$ & 2271 & $18 \cdot 30$ \\
\hline & 2251 & $99 \cdot 70$ & E-2 & $79 \cdot 60$ & 2291 & $16 \cdot 50$ \\
\hline & 2237 & $90 \cdot 10$ & 2202 & $35 \cdot 80$ & 2218 & $41 \cdot 30$ \\
\hline & 2268 & $130 \cdot 00$ & 2232 & $53 \cdot 50$ & 2289 & $15 \cdot 40$ \\
\hline & Mean & $102 \cdot 63^{a}$ & - & $59 \cdot 62^{\mathrm{b}}$ & - & $22 \cdot 89^{\circ}$ \\
\hline & $\mathrm{SE}$ & $9 \cdot 39$ & - & $9 \cdot 56$ & - & 6.17 \\
\hline
\end{tabular}

$\mathrm{a}, \mathrm{b}, \mathrm{c}$ Mean values with different superscript letters were significantly different $(P<0.01)$.

* For details of treatments, see p. 262 and Table 1.

enzyme activity was highest in group 3 animals indicating greater Se accumulation, and this might have been the cause of the toxicity symptoms of Degnala disease seen in one animal as a result of selenocysteine or selenomethionine incorporation into certain proteins in the body (Ochoa-Solano \& Gitler, 1968; Khirwar \& Arora, 1977; Tekchandani \& Arora, 1978; Kraus et al. 1983). Post-translational incorporation of Se into the GSH-Px enzyme could also have led to the high GSH-Px activity. The erythrocyte GSSG-R activity did not show any trend between treatments, probably because this enzyme was not Se-dependent.

Liver SAM concentration tended to decrease with increasing Se load, particularly with the organic Se source: this may have been because this metabolite was functioning as a 
Table 6. Erythrocyte reduced glutathione concentration ( $m g / l$ erythrocyte) of buffalo (Bubalus bubalis) injected daily with weekly incremental doses of sodium selenite (group 2) or selenomethionine (group 3)

\begin{tabular}{|c|c|c|c|c|c|c|c|c|}
\hline & Group* & Animal no. & $\mathrm{W}_{0}$ & $W_{1}$ & $\mathrm{~W}_{2}$ & $\mathrm{~W}_{3}$ & $\mathrm{~W}_{4}$ & Slope \\
\hline & 1 (Control) & $\begin{array}{c}1 \\
2 \\
3 \\
4 \\
\text { Mean }\end{array}$ & $\begin{array}{r}1039 \cdot 5 \\
730 \cdot 7 \\
670 \cdot 0 \\
593 \cdot 2 \\
758 \cdot 3\end{array}$ & $\begin{array}{l}763 \cdot 1 \\
743 \cdot 9 \\
557 \cdot 0 \\
625 \cdot 0 \\
672 \cdot 2\end{array}$ & $\begin{array}{l}787 \cdot 5 \\
837 \cdot 5 \\
725 \cdot 9 \\
560 \cdot 3 \\
727 \cdot 8\end{array}$ & $\begin{array}{l}763 \cdot 1 \\
744 \cdot 2 \\
717 \cdot 6 \\
601 \cdot 8 \\
706 \cdot 7\end{array}$ & $\begin{array}{l}688 \cdot 7 \\
653 \cdot 0 \\
781 \cdot 2 \\
798 \cdot 1 \\
730 \cdot 2\end{array}$ & $\begin{array}{r}-70 \cdot 2 \\
-15 \cdot 5 \\
38 \cdot 3 \\
38 \cdot 7 \\
-2 \cdot 2^{a}\end{array}$ \\
\hline & 2 & $\begin{array}{c}1 \\
2 \\
3 \\
4 \\
\text { Mean }\end{array}$ & $\begin{array}{l}812 \cdot 5 \\
664 \cdot 9 \\
572 \cdot 9 \\
722 \cdot 2 \\
693 \cdot 1\end{array}$ & $\begin{array}{l}762 \cdot 5 \\
458 \cdot 3 \\
276 \cdot 8 \\
750 \cdot 0 \\
561 \cdot 9\end{array}$ & $\begin{array}{l}425 \cdot 0 \\
455 \cdot 8 \\
459 \cdot 4 \\
617 \cdot 6 \\
489 \cdot 4\end{array}$ & $\begin{array}{l}337 \cdot 5 \\
486 \cdot 4 \\
433 \cdot 9 \\
350 \cdot 0 \\
402 \cdot 4\end{array}$ & $\begin{array}{l}267 \cdot 4 \\
368 \cdot 4 \\
473 \cdot 7 \\
458 \cdot 3 \\
391 \cdot 9\end{array}$ & $\begin{array}{r}-151.5 \\
-56.5 \\
-3.9 \\
-92.8 \\
-76.2^{\mathrm{at}}\end{array}$ \\
\hline & 3 & $\begin{array}{c}1 \\
2 \\
3 \\
4 \\
\text { Mean }\end{array}$ & $\begin{array}{l}843 \cdot 7 \\
662 \cdot 8 \\
892 \cdot 8 \\
603 \cdot 4 \\
750 \cdot 7\end{array}$ & $\begin{array}{l}810 \cdot 0 \\
657 \cdot 6 \\
488 \cdot 6 \\
480 \cdot 7 \\
609 \cdot 0\end{array}$ & $\begin{array}{l}720 \cdot 0 \\
409 \cdot 1 \\
652 \cdot 7 \\
244 \cdot 2 \\
506 \cdot 5\end{array}$ & $\begin{array}{l}506 \cdot 1 \\
439 \cdot 0 \\
309 \cdot 5 \\
245 \cdot 3 \\
375 \cdot 0\end{array}$ & $\begin{array}{l}325 \cdot 6 \\
287 \cdot 5 \\
397 \cdot 4 \\
144 \cdot 4 \\
288 \cdot 7\end{array}$ & $\begin{array}{r}-134.0 \\
-96.9 \\
-117.0 \\
-115.3 \\
-115.8^{b} \\
\text { SEM (df } 9) \quad 23.8\end{array}$ \\
\hline
\end{tabular}

methyl donor in the detoxification process through methyl transferases in order to form adenosyl homocysteine (Hoffman, 1975) and dimethyl selenide or trimethyl selenonium ion (Hsieh \& Ganther, 1975), an action which facilitated the process of its elimination. Additional selenite has been shown to inactivate the methionine-adenosyltransferase (EC 2.5.1.6) enzyme system (Hoffman, 1977), and this inhibition might also have prevented the replenishment of SAM. Thus, organic Se sources such as selenocysteine and selenomethionine seem to accumulate in tissues, leading to certain changes and induction of symptoms of Degnala disease.

\section{REFERENCES}

Arora, S. P., Kaur, P., Khirwar, S. S., Chopra, R. C. \& Ludri, R. S. (1975). Selenium levels in fodders and its relationship with Degnala disease. Indian Journal of Dairy Science 28, 249-253.

Ehlig, C. F., Hogue, D. E., Allaway, W. H.\& Hamm, J. (1967). Fate of selenium from selenite or selenomethionine with or without vitamin $\mathrm{E}$ in lambs. Journal of Nutrition 92, 121-126.

Ganther, H. E., Hafeman, D. G., Lawrence, R. A., Serfass, R. E. \& Hoekstra, W. G. (1976). Selenium and glutathione peroxidase in health and disease. In A Review on Trace Elements in Human Health and Disease, vol. 2, pp. 165-234 [A. S. Prasad, editor]. New York: Academic Press.

Ganther, H. E. \& Hsieh, H. S. (1974). Mechanisms for the conversion of selenite to selenides in mammalian tissues. In Trace Element Metabolism in Animals, vol. 2, pp. 337-354 [W. G. Hoekstra, J. W., Suttie, H. E. Ganther and W. Mertz, editors]. Baltimore: University Park Press.

Hafeman, D. G., Sunde, R. A. \& Hoekstra, W. G. (1974). Effect of dietary selenium on erythrocyte and liver glutathione peroxidase in the rat. Journal of Nutrition 104, 580--587.

Hoffman, J. L. (1975). Selenium toxicity and methyl group metabolism. Federation Proceedings 34, 924 Abstr. 3991.

Hoffman, J. L. (1977) Selenite toxicity, depletion of liver S-adenosylmethionine, and inactivation of methionine adenosyltransferase. Archives of Biochemistry and Biophysics 179, 136-140.

Hsieh, H.S. \& Ganther, H. E. (1975). Acid volatile selenium formation catalysed by glutathione reductase. Biochemistry 14, 1632-1636.

Khirwar, S. S. \& Arora, S. P. (1975). Tissue distribution and excretion pattern of ${ }^{75}$ Se in animals. Journal of Nuclear Agriculture and Biology 4, 5-8. 


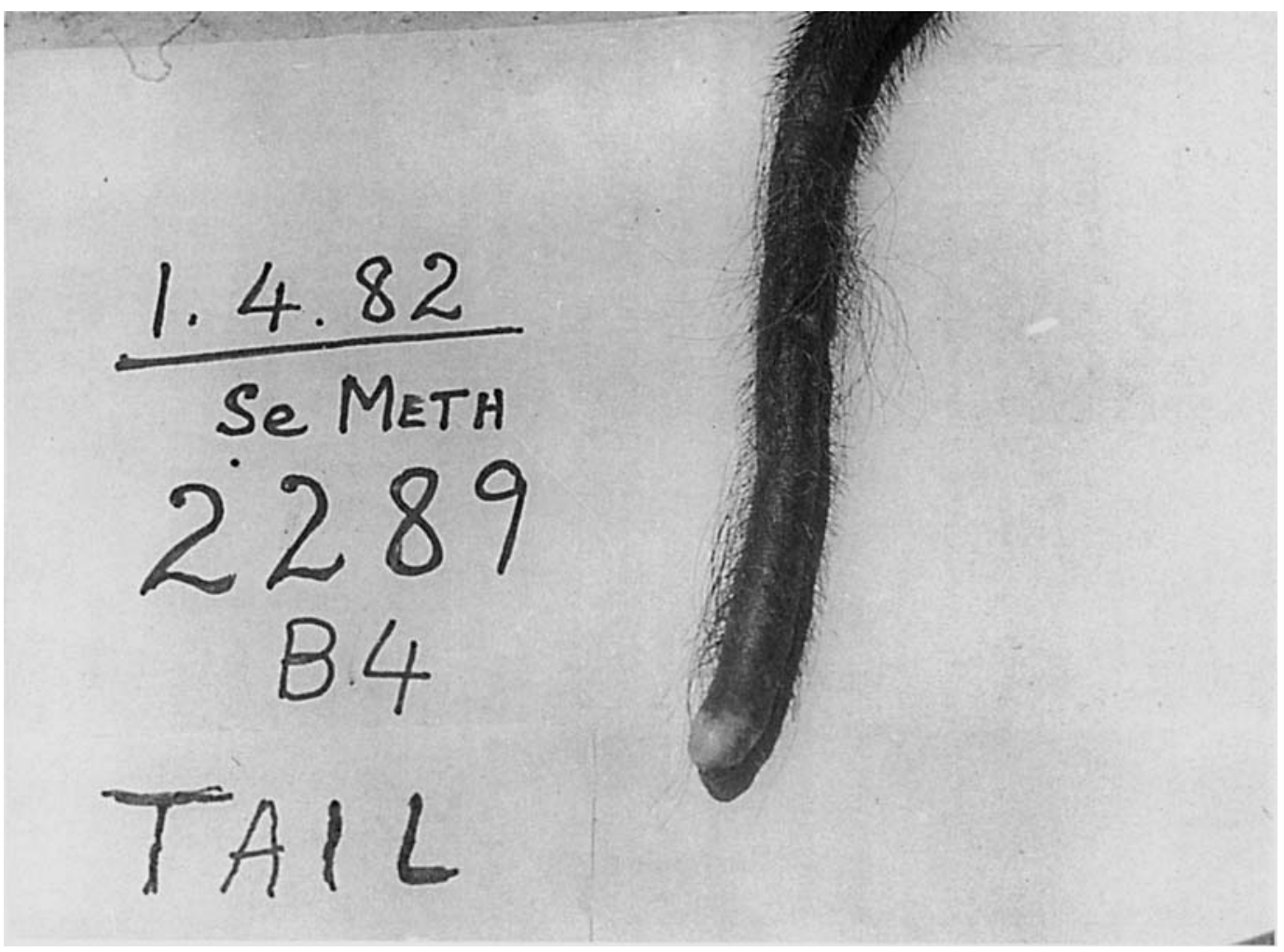

Plate 1. Loss of hair from tail, and tail tip necrosis in buffalo (Bubalus bubalis) calves receiving selenomethionine as the selenium source, with the tail switch having dropped off. 


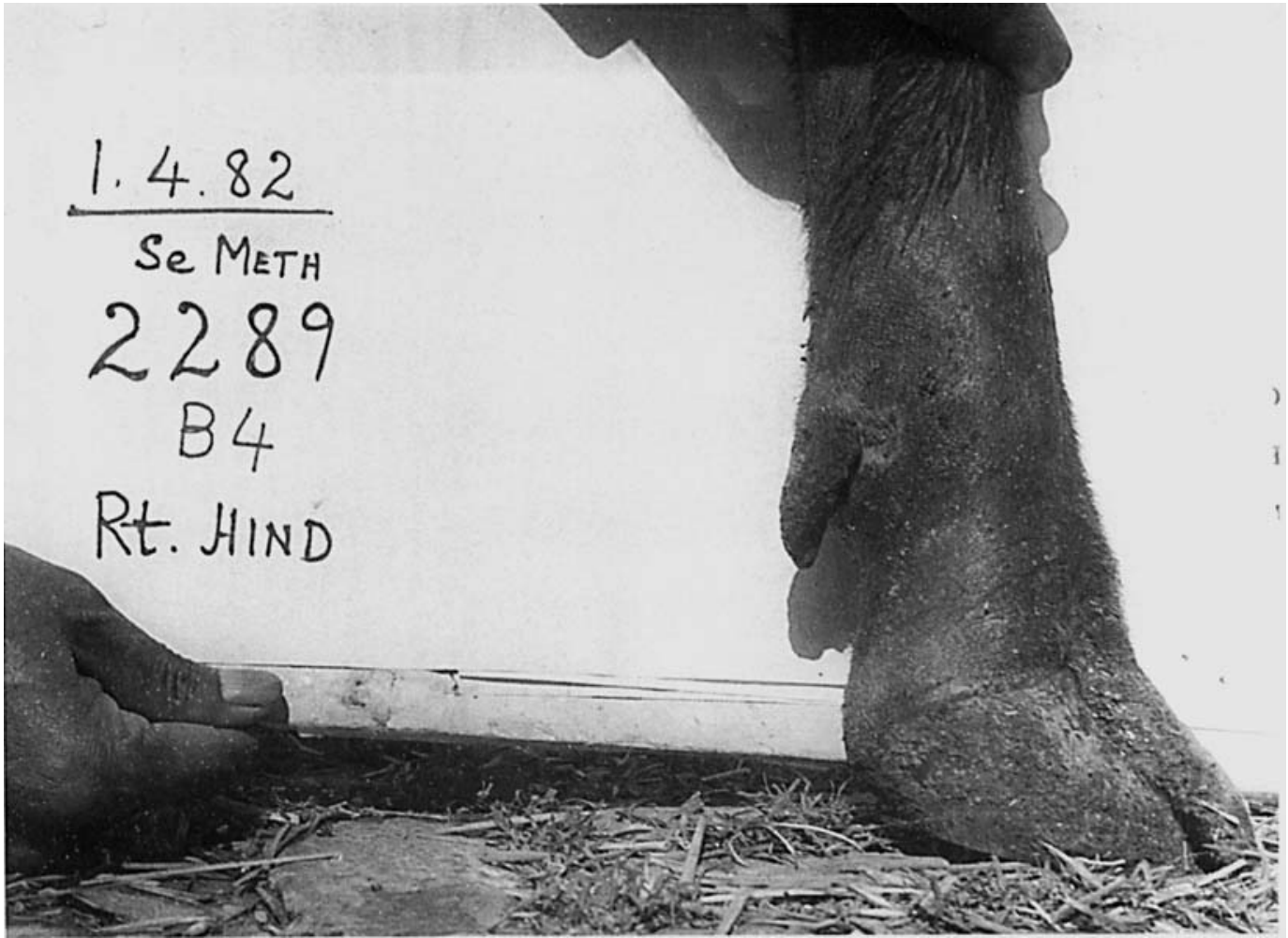

Plate 2. Wounds on the skin of legs near the coronary band of buffalo (Bubalus bubalis) calves receiving selenomethionine as the selenium source. 
Khirwar, S. S. \& Arora, S. P. (1977). Incorporation of ${ }^{75}$ Se-Selenomethionine in milk proteins of goats. Milchwissenschaft 32, 283-285.

King, J. (1965). Practical Clinical Enzymology, pp. 70-74. London: Van Norstrend Company Ltd.

Kraus, R. J., Stephen, J. F. \& Ganther, H. E. (1983). Identification of selenocysteine in glutathione peroxidase by mass spectroscopy. Biochemistry 22, 5853-5858.

Lee, M., Doug, A. \& Yano, J. (1969). Metabolism of ${ }^{75}$ Se-selenite by human whole blood in vitro. Canadian Journal of Biochemistry 47, 791-797.

Lowry, O. H., Rosebrough, N. J., Farr, A. L. \& Randall, R. J. (1951). Protein measurement with the Folin phenol reagent. Journal of Biological Chemistry 193, 265-275.

Mathias, M. M., Hogue, D. E. \& Loosli, J. K. (1967). The biological value of selenium in bovine milk for the rat and chick. Journal of Nutrition 93, 14-20.

Ochoa-Solano, A. \& Gitler, C. (1968). Incorporation of ${ }^{75} \mathrm{Se}$-selenomethionine and ${ }^{3 \mathrm{~S}} \mathrm{~S}$-methionine into chicken egg white proteins. Journal of Nutrition 94, 243-248.

Jison, O. E., Palmer, I. S. \& Carry, E. E. (1975). Modification of official fluorimetric method for selenium in plants. Journal of the Association of Official Analytical Chemists 58, 117-121.

'rasad, T. \& Arora, S. P. (1980). ${ }^{75}$ Se accumulation in rice plants and its effect on yield. Journal of Nuclear Agriculture and Biology 9, 77-78.

Prasad, T. \& Arora, S. P. (1984). Influence of feeding high and low selenium rice straw on erythrocyte glutathione peroxidase activity and blood selenium concentration of buffalo calves. Indian Journal of Animal Nutrition 1 , $1-4$.

Prins, H. K. \& Loos, J. A. (1969). Glutathione. In Biochemical Methods in Red Cell Genetics, pp. 115-137 [G. J. Yunis, editor]. New York: Academic Press.

Rosenfeld, I. \& Beath, O. A. (1964). Selenium: Geobotany, Biochemistry, Toxicity and Nutrition, pp. 130-169. New York: Academic Press.

Rowell, J. G. \& Walters, D. E. (1976). Analysing data with repeated observations on each experimental unit. Journal of Agricultural Science, Cambridge 87, 423-432.

Salvatore, E., Utili, R., Zappa, V. \& Shapiro, S. K. (1971). Quantitative analysis of S-adenosylmethionine and Sadenosylhomocysteine in animal tissues. Analytical Biochemistry 41, 16-28.

Sen, K. C., Ray, S. N. \& Ranjhan, S. K. (1978). Nutritive Value of Indian Feeds and Feeding of Animals. Indian Council of Agricultural Research Bulletin no. 25. New Delhi: Indian Council of Agricultural Research, Naba Mudian Pvt. Ltd. Press.

Snedecor, G. W. \& Cochran, W. B. (1968). Statistical Methods, 7th edn. Ames: Iowa State University Press.

Tekchandani, N. \& Arora, S. P. (1978). Incorporation of ${ }^{75} \mathrm{Se}$-selenomethionine in rabbit tissue proteins and rumen microbial proteins in the cow. Indian Journal of Dairy Science 31, 345-349. 